\title{
How to become a fake celebrity: the resurrection of Hebe Camargo, the Brazilian godmother
}

Como se tornar uma celebridade fake: a ressureição de Hebe Camargo, a madrinha do Brasil

Louise Scoz Pasteur de Faria*

* Universidade Federal do Rio Grande do Sul - Porto Alegre, RS, Brazil louisescoz@gmail.com https://orcid.org/0000-0002-2140-6523

Ruben George Oliven ${ }^{* *}$

** Universidade Federal do Rio Grande do Sul - Porto Alegre, RS, Brazil ruben.oliven@gmail.com https://orcid.org/0000-0003-3556-6955 


\begin{abstract}
How is it possible to become a celebrity by impersonating one? This is the question we pose in this article by exploring ethnographically the digital life of @hebecamargo, a fake celebrity profile created by Victor Calazans, known for being a social media guru in the Brazilian advertising industry during the years of 2012 and 2013. The emergence of fake celebrity profiles in the social media landscape is crucial to reflect upon the ways in which subjects are engaged with digital technologies throughout their lives and its power effect in the productive chain of media and celebrity. Drawing from contemporary writings, we seek to stress the importance of fakes as a means to explore dynamics of late modernity relating to power, media and subjectivity.
\end{abstract}

Keywords: imitation; celebrity fake profiles; Hebe Camargo; Victor Calazans.

\title{
Resumo
}

Como é possível se tornar uma celebridade se passando por uma? Essa é a reflexão que desenvolvemos ao longo desse artigo, explorando etnograficamente a vida digital de @hebecamargo, o perfil falso da apresentadora Hebe Camargo criado por Victor Calazans, conhecido guru de mídias sociais entre os anos de 2012 e 2013. A emergência de perfis falsos de celebridades em plataformas de mídias sociais é um fenômeno crucial para pensar sobre os modos através dos quais nos envolvemos com tecnologias digitais e em seu poder de produzir efeitos na cadeia produtiva dos media. A partir de contribuições contemporâneas, buscamos ressaltar a importância de fakes como um meio de explorar dinâmicas latentes da modernidade tardia em relação a poder, mídia e subjetividade.

Palavras-chave: imitação; perfis falsos de celebridades; Hebe Camargo; Victor Calazans. 


\section{Introduction $^{1}$}

Due to the overlapping of traditional and contemporary digital media, ordinary people can now achieve stardom and celebrity status by making themselves appealing to an audience in social networking sites. This process gives shape to a phenomenon called internet celebrity. Because of their overwhelming popularity and, above all, their capacity to influence online audiences, internet celebrities attract increasingly larger advertising investment and become signs of a new era: the age of digital fame.

Internet celebrities frequently tread a thin line between portraying facts and inventing fiction. They present us with the question of the blurred borders between the presentation of reality and the construction of fake. They thus pose us with the question of imitation and copy, a pivotal theme for the social sciences.

In this article, we seek to contribute to the debate on the issue of copy from an anthropological standpoint devoting our attention to a specific phenomenon: the production of a Fake Celebrity Profile. When fakes are successful, there is a relationship between power and authority worth exploring.

This bears the question: how is it possible to become a celebrity by feigning to be one? What enables the emergence of this kind of celebrity? Fundamentally, can we begin to grasp the complexity of the media environment through the phenomenon of internet celebrity and fake celebrity profiles?

This brings our reflection closer to broader discussions concerning the way contemporary subjects engage themselves with the issue of fake and digital media throughout their lives and in which way the boundaries of truth and false are constructed, maintained and negotiated throughout realms of experience. In particular, it is an opportunity to think about the ways through which we build ourselves amongst machines, networks, and digital imagery. Such critical issue defines the contemporary reflexive landscape of anthropological inquiry especially addressed by scholars situated within the field

1 The research for this article was funded by CAPES (Coordination for the Improvement of Higher Education Personnel) and CNPq (National Council for Scientific and Technological Development). 
of Digital Anthropology, since "the digital, as all material culture, is more than a substrate; it is becoming a constitutive part of what makes us human". (Miller; Horst, 2012, p. 4). That is in resolute opposition to approaches that imply that technology and the digital world are forces of dehumanization, rendering us less human, less authentic or more mediated. The digitalization of everyday life is a new realm of human action, therefore, poses new questions regarding agency, hierarchy, and power structures.

@hebecamargo was one of the most prominent internet celebrity profiles in Brazil, rising to fame after great media controversy. In January 2010, Hebe Camargo, television presenter and central figure of Brazilian media establishment, was hospitalized in the Albert Einstein Hospital in São Paulo. The media coverage, to the surprise of many, focused on how she made an impressive rapid recovery to the point of organizing races and parties in the wards of the hospital. The story was a hoax created by Victor Calazans, at the time an advertising and marketing college student that had created Hebe's fake profile six months earlier as part of a joke with his friends. Overnight, Victor saw himself as center of a media whirlwind.

We seek to explore in this article @hebecamargo's conditions of production - what leap of the imagination does it entail for someone like Victor to take the perspective of a TV personality like Hebe Camargo - and its public reception - what made the profile provoke media controversy so effectively that made people ignore the fact that @hebecamargo was a fake.

We argue that the power of fake celebrities' profiles does not lie on the deception remaining undetected. Rather, the deception is still authoritative enough to have a social effect. What makes @hebecamargo particularly interesting is precisely its capacity to showcase new power structures within the media industry. The façade of playful mimicry reveals a powerful truth: new communication technologies are not making the world more transparent. In many cases, technology helps to fool us to believe in what we wish to be true.

The ethnographic fieldwork upon which this article is based was composed as a bricolage of virtual and face to face semi-structured and informal interviews with Victor Calazans and his coworkers from July 2012 to July 2013 and participant observation in the annual event youPix, that took place on July 2012 in São Paulo. We also collected data from @hebecamargo's social media profiles on Twitter, Facebook and Instagram during the same period. 
We articulate our arguments in the following six sections. The first, "On being a celebrity", discusses the relation between fame and celebrity and argues that the latter is a formation that accompanies individualism and is a result of modernity. The second, "The Brazilian godmother", examines the role of Hebe Camargo as a founding figure in Brazilian television and a representation of underlying social structures of womanhood, kinship and domestic life. The third, "Enter Victor Calazans", reflects upon the emergence of a new internet celebrity by exploring the media controversy that surrounded his role in reporting Hebe's health condition in 2010 . The fourth, "Media landscapes as tension-laden fields", reflects ethnographically on the significance of internet celebrities in a context of changing power structures within media industries caused by emergent communication technologies and social networking platforms. Finally, the fifth, "What happens with a fake celebrity profile after the death of its muse?", sheds light on the aftermath of Hebe Camargo's death on her Fake internet Profile and the strategies Calazans had to put in motion in order to maintain his status of social media expert.

\section{On being a celebrity}

Celebrity is a phenomenon that is present in everyday life and has drawn growing attention of the social sciences and media studies. There are celebrities in different continents, and they are closely related to the media, mainly television. Fame is frequently seen as the starting point for thinking about the production of celebrity and the two terms are not mutually exclusive but keep a complex relation of interdependence. Inglis (2010) argues that while renown was in the past assigned to men of high accomplishment like jurists, clerics and scholars who brought honor not to them but to the office they occupied, celebrity is associated with glamour. For him, "The rise of urban democracy, the two-hundred-year expansion of its media of communication, together with the radical individualization of the modern sensibility made fame a much more transitory reward and changes public acclaim from an expression of devotion into one of celebrity" (Inglis, 2010, p. 5).

In analyzing the relation between fame and celebrity, the latter is seen as a formation that accompanies individualism, a landscape of renown that values 
social mobility more than the adherence to traditional systems of status. Ortiz argues that celebrities are a result of modernity. For him

Celebrities would depend on a high visibility of its individualities, this would only be possible if the flow of information to the large public would be really intense. In this sense, the quality of the mass media, that is, its technological and communicational efficacy would be intrinsic to the phenomenon itself. The invention of photography and cinema, the proliferation of mass press, the appearance of modern advertisement, the advent of radio and television have become essential elements for the constitution of a celebrity culture. (Ortiz, 2016, p. 672, our translation).

Robert van Krieken (2012) in his proposition of a sociology of celebrity ascertains that the different visibility of groups and individuals from the presence of power, status and wealth, asymmetrically distributed, is not enough to explain such a phenomenon. Celebrity composes a certain landscape of renown, the product of an intersection of many historical developments, changeable mutations and distinct transformations. This triggering would be related to the formation of the modern State and the growing value attributed to individualism, the emergence of the public sphere, and the media as well as processes of democratization, growing differentiations and social density. For him, "Celebrities are in many respects democratized aristocrats, both the subjects and the objects of power relations" (Krieken 2012, p. 8, original emphasis).

Newspapers and magazines assume a crucial role of making faces and names circulate and contribute to produce the "frenzied rhythm" of the big cities, their atmosphere of novelty and cosmopolitanism. Celebrities are an essential aspect of the creation of cosmopolitanism. Their constant presence helps to institute a specific temporality, aesthetic, and narrative to urban living.

Thus, the media institutes its intimate relationship with celebrity. Without the frisson sparked by celebrities helping to create new audiences and diversify channels, media outlets would hardly survive. Digital media have complexified and amplified this process even more by dispersing its chain of production and creating new ways to interact with entertainment content. The relationship between celebrity, mass media and mimesis is of substantial importance to contemporary anthropological perspective on fakes. 


\section{The Brazilian godmother}

Hebe Camargo is a name intertwined with the history of Brazilian television. Known as the "godmother of Brazilian television," she began her career as a singer in the 1940s and became a television star in the 1950s when television was introduced in Brazil. She hosted her own TV show called "O Mundo é das Mulheres" ("The World belongs to Women") in Rede Tupi, the first TV network of the country. The program was a hit and she became the greatest name of the network. Her star quality attracted attention of television networks that came after Rede Tupi. From then on, Hebe Camargo was seen on almost every television station in Brazil. In the 1960s, she presented "O Show da Hebe" ("The Hebe Show") on TV Record, the highest rated TV show during the late 1960s and 1970s, when she debuted as an interviewer.

It wasn't until the 1980s that she established herself as the greatest female persona of Brazilian television with a talk show called "Hebe" broadcasted uninterruptedly for twenty-seven years on SBT and Rede TV networks. "Hebe" was one of the longest running TV shows and had a deep impact on primetime schedule airing on Monday's evenings. The show was cancelled in 2012 due to the death of Hebe Camargo at the age of 83 .

The power of Hebe's image was intimately linked to her ability of appearing as an equal among her public. Lovable, supporting and always in good spirit, she was perceived as any traditional Brazilian housewife would like to see herself: a friend that doesn't demand anything more than a good chit-chat and lots of laughs. She was portrayed in television and celebrity magazines as "that neighbor to whom you ask for some salt or garlic. And, from a neighbor, nothing but a good talk is demanded, a good gossip, a good laugh". She was "always laughing, the whole of Brazil, north to south, knows her good humor and her likability [...] simplicity, good humor, easy smile, empathy, warmth, gracefulness are some of the qualities which composed her exemplary public figure" (Miceli, 1972, p. 51-52, our translation).

Her show was designed especially for her "godchildren viewers" so they could feel free from the frustration of ordinary life, celebrating in a ritualist way an ideal of domestic life. Miceli considers that this was a strategy of "absolute appreciation of the emotional realm, translated into tenderness, warmth, optimism, love, hope [...] the language of the heart carries 
out the naturalization of this social experience" introducing an "atmosphere of make-believe free from social tensions" (Miceli, 1972, p. 77, our translation).

Her popularity rendered her such proximity to the audience that she became part of the Brazilian family. Hebe was not simply a TV hostess but was instead commonly referred as the "Brazilian TV godmother", an important and pivotal role.

The image of the godmother resonates deeply in Brazil. As in other countries, with a rooted Christian tradition, the figure of the godparent is very important. Many children are given godfathers and godmothers when they are born, and those symbolic relatives are supposed to protect their godchildren mainly when they are in hardship or danger. Being a godparent also entails taking the place of biological parents when they die.

Considering that the Brazilian State is frequently unable to fulfill its role in providing for services that are needed, having a powerful godparent is important for the less privileged. Politics and business are also frequently based on the idea of people who help and protect others through social networks (Hutchinson, 1966).

Religion is another an area in which having protectors is very present in Brazil. Catholicism, the largest religion of the country, is strongly based on having a saint-protector. In popular Catholicism, it is common for an individual or even a community to establish a relation of alliance with one or more saints with whom they keep special obligations in order to count on them as their protectors. In critical or difficult situations, the relation with the saint protector can become contractual. Through it the believers commit themselves to carry out certain obligations, especially in exchange for the solution of specific problems. In this case, the resolution of problems is considered the grace attained, a blessing of the saint protector (Zaluar, 1983).

In the same vein, in African-Brazilian religions believers have their orixá, deity that guides and protects them. One of the tenets of African-Brazilian religions is the belief that people have a special bond with an orixá, considered an orixá de cabeça ("head orixá") and orixá protector. The relation of the followers with their orixá is made up of constant obligations. In this way, they believe that they may count on their orixá protector to face and overcome all the moments of affliction that occur in their live (Rabelo, 2015). 


\section{Enter Victor Calazans}

At the age of 81, Hebe Camargo was the center of great media speculation regarding her capability to carry on with her TV show on SBT network. The great issue was her medical condition. After a sudden hospitalization in January 8th 2010 (Hebe..., 2010a; Hebe..., 2010b; Prado, 2010; Soares, 2010), signs of her deteriorating health sparked alarming media reports. The official medical statement of Albert Einstein Hospital referred to a surgical procedure. However, rumors widely circulated among media professionals about the seriousness of her case without confirmation by the medical staff or her family.

Expectation grew as the public waited for novelties on Hebe's condition, prompting a wild competition among media vehicles. Professionals in search of new developments on her health didn't take long to detect a great startle on Twitter. Izilda Alves, a reporter working for Jovem Pan Radio Station, was at that time looking for news about Hebe in websites and social networks when she noticed an unusual activity regarding the case.

Many Twitter users were making direct references to a profile named @ hebecamargo sharing her adventures in the hospital ward. The content of the tweets was clearly humorous. According to the story posted, Hebe Camargo was running wheelchair races at the Intensive Care Unit and having her intravenous serum watered with vodka.

The reporter took @hebecamargo as if it were Hebe's official Twitter profile, turning her hospital adventures into national headlines. This fantastic narrative did not make the journalist question its reliability. Izilda's article described Hebe Camargo so well as to organizing races and parties in the wards of the hospital. Different media outlets started to pick up on the story and broadcast it as if it were true.

The headline immediately drew the attention of the public, seduced by a story which bordered on fiction. But the farce was soon to be discovered. The journalist had been the victim of a prank, even if an unintentional one, of a fake celebrity profile. From a little more than 1,000 followers, the profile jumped to 62,000 in a few hours. The media's attention was now drawn to a parallel subject: who was the brain behind the "Online Hebe"? Articles in newspapers and television described the author as somebody ill-intentioned, making money by playing Hebe. 
The story was a prank made up by Victor Calazans. By creating a hoax Victor became the center of a media whirlwind overnight. The event placed him among the Brazilian 'high social media', a term used as a reference to an elite composed by influent people with many followers. Today, @hebecamargo has over 65,000 followers on Twitter and 13,000 likes on Facebook. The profile remains one of the most successful fake celebrity profiles in the history of Brazilian social media.

The controversy around Hebe Camargo fake celebrity profile fueled a serious discussion about journalism in the digital era: how can we trust journalists to provide quality information if they are so easily fooled by an internet hoax? By taking advantage of the media speculation the creator of @hebecamargo raised up from anonymity and became a digital guru and internet celebrity. In little more than five months, Victor Calazans went from a social communication student to a social media specialist, invited to events and advertising agencies. He became a platform to advertise products and services to a younger generation no longer influenced by traditional media channels like television, radio, magazines and newspapers.

Media articles emphasized the apparent strangeness of internet fame: the relationship between @hebecamargo and its creator, the issue of public visibility and anonymity, the life of a celebrity inside and outside the digital world. Most of all what drew attention was the humoristic dimension of the profile that created, through parody, a reversed Hebe, one that is not sweet and approachable, but acid and tongue-in-cheek.

Victor, who became an internet star when he was 26-year-old, now enjoyed his new-found status. He had achieved a level of recognition that just few other professionals had throughout their whole careers. This ability seemed to be acquiring more and more market value in contemporary media industry. What we used to hear during fieldwork was that he possessed a rare expertise: he could attract the attention of an increasingly dispersive audience in many different media platforms. That was a rare expertise, in the sense of the formation of a sensibility and cognition incorporated to knowings and doings (Chevallier, 1991).

To Victor, his success was a product of his own efforts of creating a distinctive character and narrative involving such a high-profile media figure in Brazil. In his own words, he had created a different version of Hebe fit for internet 
humor: filled with metanarratives, ironies, and references to pop culture playing with our own difficulty to separate real from fake in social media times.

\section{Media landscapes as tension-laden fields}

To understand the process through which an individual becomes famous we cannot make a hard distinction between deprecating rumors and high-flown compliments since both dynamics play an important role in establishing fame in mutual reinforcement. The tensions among different agents and political instability inherent to the ascent of @hebecamargo to celebrity status were constant throughout fieldwork. The reason why Victor had become such an interesting media character was due to the significant number of articles that either deprecated or complimented his story in similar proportion, rejecting or hailing @hebecamargo with a certain degree of exaggeration. The articles themselves seemed to compete for the public's attention, resulting in a distortion between fact and fiction that Elias and Scotson call blame gossip and pride gossip. The extent of the public image and status of individuals gossip depends on what those authors have called individual and shared self-image: "the more threatened and insecure they feel, the greater the probability that internal pressure and, as part of it, internal competition lead to collective beliefs and extremisms of illusion and doctrinaire rigidity" (Elias; Scotson, 2000, p. 125-126).

@hebecamargo and Victor became known to the public and the digital media market not because of their good name, but mainly for being ill-spoken of. It was the public's negative reactions and the attempts to link to their names deprecating aspects associated to digital media that have fed the curiosity and incited agents in his defense, producing a flow of rumors that has attracted many readers. Ultimately, one version of the story prevailed: the one that situated Victor as an important player in the digital media landscape.

Victor was recognized as one of the "new faces of a communicational revolution", not a menace to Hebe Camargo's public image. Camargo's managing team even embraced @hebecamargo as part of their online branding strategy aiming to target a younger audience that no longer was attracted to television or magazines. 
However, being a digital celebrity was part of a controversial debate in the digital media industry. Many professionals we encountered during fieldwork expressed a contrary position to what they perceived as an ever-growing attention drawn by internet celebrities. They understood the growing interest in celebrities as a sign of the decrease of critical thinking in the public sphere manifested in their appetite for "empty humor" and "endless jokes".

Victor himself had already expressed to us his views on the status of internet celebrity on many occasions. Victor used to say people were becoming more and more interested in digital celebrity in search of "easy fame" and were no longer preoccupied with creating "interesting and creative content": they just "copied other internet celebrities" instead of "creating characters and narratives of their own". Paradoxically, he was making use of the same argument posed against him in many other occasions: that he was a fake.

Victor participated at a round table on the influence of social media in Brazil that took place in 2011 at the Social Media Week, held at the Fundação Armando Álvares Penteado, a business and advertising college located in São Paulo. In that occasion, media professionals arrived at the conclusion that "Brazilian users have not yet learned how to use social media". Instead of creating new content, they just wanted to "make fun of people and share comments on Big Brother". The panel directed their critiques to "common people" who, like Victor, "used social networks just for fun" and ended up being idolized by a huge mass of followers.

Maybe, just as Victor, they had to deal with the perspective of technical obsolescence, which could not be dissociated from the fluctuation of their status and social position within the media landscape. Since the advent of social media, journalists experimented a feeling of displacement. New agents were coming into the media scene and competing for audiences. For Victor, what seemed particularly worrying was the realization of how short the media cycle of a digital celebrity was. He felt that soon enough he would be part of internet history given the amount of "new faces" emerging every single day.

This seems to be a starting point to understand an acute passage of Victor's life narrative. A journalist from Record TV Network contacted the company in which he worked in mid-2011, asking for an interview on how to use technical resources from Twitter. Victor accepted the invitation, and the interview was recorded at his home. Without Victor's knowledge, the journalist discovered 
that he was the creator of @hebecamargo and kept this piece of information secret up to the moment of the interview. At the end of the conversation, when the journalist felt they had established a relationship of trust, she asked about the fake celebrity profile he had created. Victor confirmed that he was @hebecamargo, giving start to many other questions on internet, celebrity and his relationship with Hebe Camargo.

When the interview went on air the following day, Victor was baffled to find out the he had become the central character of a piece on internet crimes. Victor was being sponsored and this put him in a delicate position in face of Brazilian law, which sees this as false representation, since he would be profiting on someone else's public image while this person is still exercising their profession. In his recollection of events, this episode appears as if it was some sort of retaliation from the "traditional media" attacking a very sensitive aspect of how he saw himself: not as a fake, but as a creator.

The notion of fake was articulated by him with great moral weight. The accusation of having copied someone was very degrading for him, the creator of @hebecamargo, and to say that he was a fake meant that he would "surf any hype as long as it could render him more followers, more audience and sponsorship contracts" as he told us in an interview. Calling @hebecamargo a crime felt like a cruel attack since it put into question central aspects of his sense of self.

Tom Boellstorff (2008), in his ethnography of Second Life, noticed the centrality of notions of "role" and "screen name" in producing borders between the "online" and the "offline" selves. Such constructions operated as autonomous centers of action guided by their own rationalities, such as an actual and a virtual self. ${ }^{2}$ A distance between the virtual and the actual is produced, which would be fundamental to the crystallization of a culture in online worlds. However, such distance wasn't insurmountable. The virtual and the actual selves interacted in his subject's daily lives. For many of his interlocutors, "This sense of permeable membrane between the self of the actual world and the self

2 Boellstorff (2008) uses the terms virtual and actual to account for the production of difference between what is within and what is outside virtual environments in an ethnographic sense, not ontological. 
of the virtual world was experienced in positive terms. Their online lives could make their actual self more real" (Boellstorff, 2008, Kindle Location 2556). Boellstorff (2008) understands that the visual and textual substrate upon which action is possible in virtual worlds are the very modality from which the notion of self may be experienced.

However, the perspective of common people with no technical training occupying the social role previously reserved to media professionals could also sound problematic not only for this professional group, but it also implies profound changes in the media industry.

A consistent reflection on the establishment of the media in Brazil cannot escape an attentive analysis of how the media was intertwined with state policies in efforts to build a sense of belonging related to an idea of nation-state. This debate extrapolates the purpose of this article, but it is possible to reflect on the role of digital and social media in the rearrangement of power in the media industry.

During fieldwork we frequently heard from media professionals and journalists that digital media was damaging serious journalistic investigation. They told us that users of social media platforms didn't have enough patience or focus to be able to read texts "over 140 characters" and that their hunger for novelty and lack of critical thinking made them prone to believe in fake news. This scenario would also be putting pressure on media professionals to increase the speed and number of daily publications, compromising the process of sourcing and double-checking information. Digital media, to many, was not making the world more transparent. It was rendering information even more opaque.

In relation to the modes of production in social communication, Lima Junior (2009) considers that much of what defines traditional media lies on the distance between media outlets and viewers as well as in an idea of journalistic authority historically situated from the 1950s and built on ideas of objectivity, impartiality, and neutrality. However, the internet not only brought these two spheres closer as it converted amateurs into creators and distributors of journalistic content. Its effects go even further.

The term "audience journalism" was frequently used among media professionals during fieldwork. Big newsrooms, news agencies, TV stations and press agencies demanded their professionals increasingly to use digital resources in 
everyday processes. The term "digital" in that context did not relate solely as means of technical support in research, writing, distribution, and automation of news, but mainly as a growing preoccupation with the numeric performance of publications.

Their relevance would be based mainly on quantitative parameters: audience figures, number of visitors, replies, shares, comments, likes. Their qualitative relevance, that is, the capacity of a piece to condense and summarize a complex public debate from different perspectives was becoming more and more secondary and, in some cases, even dispensable.

Many of those media professionals used to tell stories about colleagues who had lost their jobs for not "meeting the goal of number of accesses, shares and likes defined by the editor." These narratives lead us into thinking about the limits of technology. More than expressing dissatisfaction, these subjects showed a disposition in negotiating with technical devices themselves. How could it be possible to produce a less symmetrical relationship with technology and constructively absorb its effects? What are the frontiers between the machine and humanity? What is my role in an ever-changing world?

These were questions that could unite internet celebrities and journalists working under new conditions of information production. These subjects experienced traditional and digital media through a logic that privileged productivity, performance, numbers and the ongoing emergence of novelties that shape a new economy of attention. @hebecamargo would not exist without "audience journalism".

It was the immense demand on news that prompted Izilda Alves to publish a piece without double-checking facts even faced with a story that seemed a bit too fantastic to be truthful. This dynamic is a product of growing instability, unpredictability and competitiveness within the media industry produced by a growing technological demand.

There is a relationship, more of complicity than analogous, between those distinctive spheres that compose the contemporary media landscape according to the narratives of media professionals. Both traditional and digital media produce new asymmetries and even reinforce old power structures that shape media industries. The emergence of fake celebrity profiles is only one possible manifestation of a wider phenomenon that situates falsity at the center of global forms of political practice and imaginary. 


\section{What happens with a fake celebrity after the death of its muse?}

Hebe Camargo's health condition was subject of speculation since August 2010. Her managing staff and family faced with public demands for news found no way other than publicizing the truth about her illness. Hebe was diagnosed with peritoneum cancer. She received heaps of solidarity. Each hospitalization, each medical procedure, every single novelty on the case received extensive media coverage and was followed by immediate public reaction. As far as the public was concerned, her condition was improving. Only her family knew about her actual life expectancy. In July 2012, her medical team announced privately that Hebe should have no more than six months to live. Hebe and her team decided not to make this information public and to continue with her TV show despite her fragile condition.

Victor knew about Hebe's prognosis. According to him, her decision to maintain an aura of joy in face of hardship was coherent with the public image she had built throughout her career on television. Even so, nothing seemed to have prepared him for Hebe's death on September 29, 2012. He was taken by surprise. Everyone around expected her to outlive the 2012 edition of Teleton - a charity TV show aired on SBT station - in November of that same year. This was her way to give her audience "a proper goodbye". Victor was invited to appear on the show side by side with Hebe as part of a comedy sketch. The plan was to introduce him as part of her legacy.

However, in the week prior to the event and due to the progression of the disease, Hebe decided to leave the hospital and go home to spend her last moments among family and friends in absolute secrecy. Hebe, after a life dedicated to the public, made her death a private event.

For much of our research relationship, Victor was discreet about his affection towards Hebe Camargo. He made every decision regarding the creation of his fake celebrity profile seem as if it was part of a calculated plan to explore falsity as a means to create a compelling narrative given her enormous popularity on television. Still, Hebe's death provoked in Victor not only a shock of consciousness regarding Hebe's role in the making of his own subjectivity, but a renewed awareness of how unpredictable social media audiences could be. 
About 300 people attended Hebe Camargo's funeral procession on September 30th. Starting at Palácio dos Bandeirantes, headquarters of the government of the state of São Paulo, the procession ended at Gethsemani Cemetery, located in Morumbi. Victor was among those 300 people. He was not allowed by Hebe's family and staff to photograph or make any comment on social media regarding the ceremony. Yet, a huge wave of condolences took over Hebe's fake profiles, urging Victor to share at least a few discreet images of Hebe's wake along with remarkable moments of Hebe on TV. During the ceremony, Victor published old photos, striking lines, excerpts from her television program, statements from friends and admirers as if he were an official member of her managing team.

There was one thing that Victor feared that he couldn't admit at that point: the death of Hebe's fake celebrity profile. In the weeks after the event, those fears seemed to be true. He had not only lost his muse but found himself immersed in events beyond his control.

The network agreed to continue the production of Hebe's TV special after her death as a tribute to her memory but one week after Hebe's death Victor received a call from the stage coordinator of Teleton canceling his appearance on the show. Stunned, Victor found a way to negotiate with the producers of the show using his influence on the internet. When he announced that he would no longer be part of the TV Special, a wave of criticism on social networking sites compelled the network to reconsider the decision. "The one who disinvited you doesn't have a clue about social media" they said to him.

With support of his followers and influential people in the entertainment business who were also booked to participate on Teleton, Victor managed to revert this decision arguing that his presence would attract a new audience and amplify the impact of the show online.

However, this would not be an isolated episode. He would soon realize that the virtual life of @hebecamargo also was in jeopardy. His audience began to respond negatively to @hebecamargo. Just right after Hebe's death, his audience seemed moved by a nostalgic narrative, but not for long. As time went by, appealing to her memory was no longer a compelling storyline. In his own words:

The day she died I gained a thousand followers, since then the profiles have kept this monthly average. But it's been hard to generate buzz. I feel that people 
don't know how to react to a fake celebrity profile after the celebrity's death. They haven't decided whether they like to see pictures, moments or remember one of her catchphrases or not. Now I could advertise the profile without any judicial restriction, but it's really complicated since I don't have a storyline anymore to make sense of it all. And there's a thing: the audience on Facebook behaves differently than the one on Twitter and on Instagram. On Instagram if I post any picture of her, I lose around 200 followers. They simply stopped following. I even talked to a friend of mine that is a metrics expert to try to understand this. I don't have an explanation yet. While they don't want to see pictures of her, they want to remember her jokes and special moments on Facebook or Twitter.

Faced with the incomprehension of his audience, Victor became increasingly skeptical about @hebecamargo's potential to survive his muse's passing. During our conversations, he constantly manifested his dissatisfaction with the life of a social media expert. He used to say that the main reason why he had lost interest in @hebecamargo was that he had "totally changed the storyline of my [his] profile."

Before Hebe's death, he articulated @hebecamargo's narrative as if it were the

Daily life of a living person. Morning, afternoon, night. One moment, she is commenting on something that happens in heaven. In another, she is focusing on what happens on earth. Those are two very different dimensions and are related to two distinct scales of events. I must know how to handle it. Before, I had plenty of material to work with: her TV show. The character is now an omnipresent being. She in heaven, she on earth, she's in Miami at the same time. I must study and come up with some way to ordain this kind of content.

However, not everything seemed lost. Victor was surprised to know that the market value of @hebecamargo had increased after it became a fake celebrity posthumous profile. Sponsors who had previously been careful to associate themselves with a fake celebrity profile now were not so reticent anymore mostly because they were no longer liable to legal process. Victor was not portraying a living person anymore, so technically he couldn't be accused of identity theft. 
Beyond that, Hebe Camargo was still a powerful public figure, made even more influential after her death. It was profitable to associate brands with the memory of Hebe Camargo. The public responded well to such initiatives seeing it as a means to "keep Hebe's memory alive". Victor saw this as an opportunity to find a new storyline for @hebecamargo. The profile became increasingly nostalgic. His narrative was now organized around special dates in the life of Hebe Camargo and homages of dear friends, alongside with old pictures and excerpts from her TV show.

The definitive proof of @hebecamargo profile's resurrection would come in March 2013. Victor signed a contract with one of the largest travel agencies in Brazil to sponsor a 30 days trip to seven European countries for the purpose of promoting the brand. The concept of the campaign was to take Hebe Camargo with him in this adventure through Europe, taking pictures and making videos alongside a mask portraying her face. This was the biggest advertising contract of his career. The impact of the campaign was greater than expected and the trip that originally would be completed in 30 days was extended to 70 .

Victor felt a significant change in his status as creator of a Dead Celebrity Fake Profile in an increase of demand for sponsorship contracts and through professional opportunities. This gave him the opportunity not only to sign new deals of sponsorships with many nationwide brands, but also guaranteed him an important job prospect.

Within a week after his return to Brazil he received a job proposal from a large media company to become national director of social media. Nowadays, Victor still works as social media expert and is part of the social media team of one of the major Brazilian publishing covering celebrity news, keeping @hebecamargo active for old times' sake.

\section{Final considerations}

Entities such as @hebecamargo emerge from a media landscape shaped by new communication technologies and social networking platforms and are increasingly competitive, overlapping, and opaque. @hebecamargo has only become an internet celebrity when she crossed the borders of digital media toward traditional media. This does not seem to have happened simply out of lack of 
knowledge of digital media by the journalist who was involved in this particular case, but mainly out of the new demands imposed over the productive chain of communication as a whole regarding the velocity in which news should now be produced in order to achieve the best numeric performance as possible in terms of audience.

The controversy surrounding the event served as means to fuel this dynamic rendering the relationship between digital and traditional media more analogous than conflicting. The emergence of fake profiles in such context cannot be considered a byproduct of growing competitiveness but the very engine that produces the contemporary experience of being in the world marked by ambiguity and disjunction.

The force of @hebecamargo didn't lie solely on Victor Calazan's capacity to critically manipulate Hebe's public figure exposing the symbolic tension underlying her joyful and agreeable façade. Most of all, her rise to celebrity status sheds light on how contemporary media benefits from producing falsity. @hebecamargo is a humorous example of how fakeness is now a fundamental aspect of media practice. It is by exploring opacity, anxiety and empathy that media outlets instigate the audience and stimulate their response to news in the form of shares, likes, and numeric attention.

Victor has become skilled in handling the logics of a domain that is increasingly based on visuality, performance and effectiveness. This imposes considerable psychic and social demands on him. Victor made himself as a creator in an ongoing self-conscious process of creative manipulation of false and true, articulating his existence as a celebrity and social media guru amid contradictory relationships, grandiose and powerful affects.

\section{References}

BOELLSTORFF, T. Coming of age in Second Life: an anthropologist explores the virtually human. Princeton: Princeton University Press, 2008.

CHEVALLIER, D. Des savoirs efficaces. Terrain, n. 16, p. 5-12, 1991.

ELIAS, N.; SCOTSON, J. L. Os estabelecidos e os outsiders. Rio de Janeiro: Jorge Zahar, 2000. 
HEBE Camargo é internada em hospital de São Paulo. GaúchaZH, 8 jan. 2010a. Available at: https://gauchazh.clicrbs.com.br/cultura-e-lazer/noticia/2010/01/hebe-camargo-e-internada-em-hospital-de-sao-paulo-2772164.html. Access: 30 Nov. 2013.

HEBE Camargo é internada em São Paulo. G1, 8 jan. 2010b. Available at: http:// g1.globo.com/Noticias/PopArte/0,MUL1440337-7084,00-HEBE+CAMARGO+E+IN TERNADA+EM+SAO+PAULO.html. Access: 30 Nov. 2013.

HUTCHINSON, B. The patron-dependant relationship in Brazil: a preliminary examination. Sociologia Ruralis, v. 6, n. 1, p. 3-30, 1966.

INGLIS, F. A short history of celebrity. Princeton: Princeton University Press, 2010.

KRIEKEN, R. van. Celebrity society. New York: Routledge, 2012.

LIMA JUNIOR, W. Mídia social conectada: produção colaborativa de informação de relevância social em ambiente tecnológico digital. Líbero, v. 12, n. 24, p. 95-106, 2009.

MICELI, S. A noite da madrinha. São Paulo: Perspectiva, 1972.

MILLER, D.; HORST, H. A. The digital and the human: a prospectus for digital anthropology. In: HORST, H. A.; MILLER, D. (ed.). Digital anthropology. London: Berg, 2012. p. 3-35.

ORTIZ, R. As celebridades como emblema sociológico. Sociologia e Antropologia, v. 6, n. 3, p. 669-697, 2016.

PRADO, M. A. Hospital confirma previsão de internação de Hebe. R7, 8 jan. 2010. Available at: https://entretenimento.r7.com/famosos-e-tv/noticias/hospital-confirma-previsao-de-internacao-de-hebe-20100108.html. Access: 30 Nov. 2013.

RABELO, M. C. M. Aprender a ver no candomblé. Horizontes Antropológicos, Porto Alegre, ano 21, n. 44, p. 229-251, jul./dez. 2015.

SOARES, R. Hebe Camargo está internada em SP e deve ser operada. Folha de S. Paulo, 8 jan. 2010. Available at: http://wwwl.folha.uol.com.br/folha/ilustrada/ ult90u676445.shtml. Access: 30 Nov. 2019.

ZALUAR, A. Os homens de Deus: um estudo dos santos e das festas no catolicismo popular. Rio de Janeiro: Zahar, 1983.

Recebido: 30/01/2019 Aceito: 24/06/2019 | Received:1/30/2019 Accepted:6/24/2019 